\title{
Peptides derived from plant virus VPg protein inhibit elF4E oncogene
}

Running title: Viral protein-derived peptides inhibit elF4E oncogene

${ }^{1}$ Institute of Biochemistry and Biophysics of Polish Academy of Sciences,

Pawinskiego 5a, 02106 Warsaw, Poland,

2TheREx TIMC-IMAG UJF-CNRS UMR 5525, 38706 La Tronche Cedex, France. \#Corresponding author: TheREx TIMC-IMAG UJF-CNRS UMR 5525, 38706 La

11 RG present address: Centre of New Technologies, University of Warsaw, Banacha 2c, 02-097, Warsaw, Poland.

13 Abstract, Introduction, Results, Discussion, Fig. Legends - 3034 words

\section{List of abbreviations}

AcMNPV - Autographa californica multicapsid nucleopolyhedrovirus; CBB -

16 Coomassie Brilliant Blue; CIYVV - Clover yellow vein virus; elF4E - eukaryotic

17 initiation translation factor 4E; 4E-BP, elF4E binding protein; FCS - fetal calf serum;

18 LMV - Lettuce Mosaic Virus; MOI - multiplicity of infection; MW - molecular weight,

19 ON - overnight; TMB - 3,3,5,5-tetramethylbenzidine, T. ni - Trichoplusia ni cells;

20 PBST - PBS buffer containing 0.05\% Tween-20; pi - post infection; PI - propidium

21 iodide; TEV - tobacco etch virus; TVMV - tobacco vein mottling virus; PVY - potato

22 virus $\mathrm{Y} ; \mathrm{VPg}$ - genome-linked viral protein. 


\section{Abstract}

25 Viruses of the Potyviridae family have VPg protein covalently attached to the $5^{\prime}$

26 end of their linear RNA genome. The protein interacts with the host translation

27 initiation factor elF4E that occurs in plant cells in two isoforms, one being the

28 preferable target of a given $\mathrm{VPg}$, the remaining one still acting in host protein

29 synthesis. In animal cells only one form of elF4E is directly involved in protein

30 synthesis. The human elF4E is known to be an oncogene; elevated expression of

31 elF4E leads to oncogenic transformation, cancers in animal models and poor

32 prognosis in human cancers, while reduction of the elF4E level can reverse the

33 transformed phenotype. We show that VPg protein delivery to cells containing only

34 one elF4E isoform involved in protein synthesis resulted in immobilization of elF4E

35 in the cytoplasm. The region of VPg involved in the interaction with elF4E has been

36 partially identified. Peptides derived from this region interacted better with elF4E than

37 complete VPg protein. Here we characterized one of VPg peptides, VPg5 and we

38 show that VPg5 delivered to colon carcinoma HCT116 cells is able to inhibit cell

39 growth, which is accompanied by reduction in elF4E level.

40 


\section{Introduction}

42 Potyvirus VPg is a multifunctional protein implicated in translation, long-distance

43 movement, replication and suppression of host antiviral silencing response $(1,2)$.

44 The host partner of VPg is the elF4E, an mRNA 5' cap-binding protein. The elF4E

45 and VPg are the major determinants of resistance versus susceptibility to potyvirus

46 infection; plants are virus-resistant when mutations in elF4E or in VPg preclude their

47 interaction (3 - 6). However, higher plants produce two isoforms of elF4E and

48 potyviral VPgs display greater affinity to one or the other elF4E isoform $(7,8)$. Thus,

49 although host protein synthesis is weakened upon infection, the virus cell cycle can

50 be completed since the second elF4E remains active in plant metabolism necessary

51 for virus development.

52 In human cells only one cap-binding protein, elF4E-1, directly promotes protein

53 synthesis (9), and a significant fraction of it (sometimes up to $70 \%$ ) is found in the

54 nucleus (10). In the cytoplasm, elF4E is involved in the initiation of protein synthesis

55 while in the nucleus it is implicated in transport of certain mRNAs to the cytoplasm.

56 The nuclear elF4E has an affinity for a class of mRNAs that specify the short-living

57 proteins implicated in cell cycle progression and malignant transformation (11). An

58 unchecked overexpression of elF4E can cause cell growth and malignant

59 transformation in tissue cultures and is a feature of experimental cancers, whereas

60 reduction of the elF4E level can reverse the transformed phenotype $(12,13)$.

61 Elevated expression of elF4E in human cancers correlates with poor prognosis (11,

62 14). These effects can partly be explained by a higher level of short-lived proteins

63 involved in malignant transformation, stemming from the increased elF4E-dependent

64 transport of the appropriate mRNAs to the cytoplasm. The proof of hypothesis was

65 furnished by the human trial in which the inhibition of elF4E activity in acute myeloid 
66 leukemia patients brought about quite positive results, whereby cancer remission

67 was associated with elF4E delocalization from the nucleus to the cytoplasm (15). It

68 appears that elF4E is an oncogene that acts as a node governing proliferation and

69 survival signaling $(16-18)$.

We have shown that Potato Virus Y (PVY) VPg interacts in vitro with various

71 elF4Es, including animal eIF4E (19). It was thus interesting to study what will happen

72 in the presence of VPg in cells with only one form of the elF4E factor active in protein

73 synthesis. We observed that in the presence of VPg the nuclear pool of elF4E was

74 dramatically depleted since VPg immobilized initiation factor in the cytoplasm.

75 Recently, we partially characterized the site of PVY VPg responsible for interaction

76 with elF4E, both of plant and human origin, and constructed peptides derived from

77 this region, some of which interacted better with elF4E than the complete $\mathrm{VPg}$

78 protein. We wished to show that one of VPg-derived peptides is able inhibit the pro-

79 oncogenic role of elF4E in neoplastic cells. We have chosen peptide VPg5 for further

80 work and also prepared VPg5 mutants interacting weakly with human elF4E. Delivery

81 of VPg5 to neoplastic cells in culture resulted in cell death accompanied by elF4E

82 reduction. 


\section{Results}

85 Localization of elF4E and VPg in insect cells. Upon infection with the 86 recombinant baculovirus expressing PVY VPg, the VPg protein was observed only

87 in the cytoplasm (Fig. 1A, VPg column). The endogenous initiation factor elF4E

88 localized at the beginning of infection to both, the nucleus and the cytoplasm, but at

$8960 \mathrm{~h}$ pi. was observed only at the cell periphery (Fig. 1A, elF4E column). Indeed, at

90 the beginning of infection, a significant fraction of the elF4E was in the nucleus but

91 diminished in the course of infection; at $60 \mathrm{~h}$ pi. elF4E was observed in the cytoplasm

92 only, showing significant overlap with VPg. To find out if the observed changes in the

93 elF4E localization were due to the presence of VPg, we analyzed the localization of

94 elF4E upon infection with empty bacmid and with baculovirus expressing either a

95 non-relevant protein (the domain II of HCV helicase) or VPg (Fig. 1B). At $60 \mathrm{~h} \mathrm{pi,} \mathrm{only}$

96 cells expressing VPg displayed elF4E disappearance from the nucleus (Fig. 1B,

97 lowest panel), demonstrating the specificity of VPg effect. To obtain more quantitative

98 data, after infection with the recombinant baculovirus expressing VPg the insect cell

99 nuclei were separated from the cytoplasm, and elF4E level in both compartments

100 was assessed by Western blot (Fig. 1C) followed by densitometry (Table 1). At 12h

101 a comparable level of elF4E was present in the cytoplasm and in the nucleus. The

102 nuclear pool of the elF4E diminished somewhat in the course of infection with bacmid

103 and with the helicase-expressing virus, from $51-53 \%$ down to $37-40 \%$ (Table 1 ).

104 However, upon expression of his-tagged or non-tagged VPg forms, the nuclear pool

105 of the elF4E was much more severely depleted; at 24 and $36 \mathrm{~h}$ pi it accounted for

106 only $13-18 \%$ of total cellular factor. Interestingly, VPg expression was significantly

107 lower than that of HCV helicase, which underlies the strength of VPg effect (Fig. 1C,

108 lower panel on the right). 
These experiments demonstrated that (1) about half of the total cellular elF4E

110 synthesized in the cytoplasm is transported into the nucleus, confirming results seen

111 for other eukaryotic cells (10); (2) VPg expressed alone in insect cells, despite

112 carrying the putative nuclear localization signal, is localized in the cytoplasm only; (3)

113 in the presence of $\mathrm{VPg}$, elF4E is retained in the cytoplasm, which results in depletion

114 of the nuclear pool of elF4E.

115 Interaction of VPg peptides with elF4E. Previously, upon selection of 116 proteolytically cleaved VPg protein on a column-immobilized wheat elF(iso)4E, we 117 tentatively identified an elF4E-interacting site on VPg (19). These results suggested 118 that the $\mathrm{N}$-terminal part of the VPg up to tyrosine 40 is dispensable for the interaction, 119 and that interaction site involves downstream region, starting with arginine 41 . We 120 have constructed five peptides derived from the putative interaction site and 121 expressed them in frame with the N-terminally attached GST protein, expressing 122 similarly also a complete VPg protein. These proteins after purification have been 123 used in the ELISA sandwich assay, in which peptide attached to elF4E was 124 recognized with the anti-GST antibody (Fig. 2). The interaction with wheat elF(iso)4E 125 and with human elF4E were analysed. The best interacting peptides were VPg5 and 126 VPg4 for the plant factor. The human factor interacted best with the same peptides 127 and in addition with the peptide VPg1. This shortest interacting peptide (VPg1, 19 128 aa) was contained in both VPg5 (26 aa) and VPg4 (42 aa). Also, the VPg2 contained 129 peptide VPg1 but was significantly longer and much more hydrophobic in character. 130 It attached less well to elF4E and, similarly as peptide VPg3, had a propensity for 131 forming oligomers at high concentration (results not shown). We have chosen to work 132 with peptide VPg5. In parallel we created two VPg5 mutants. Based on comparison 133 of corresponding sequences from other potyviral VPgs (Fig. 3A), we changed either 
134 tyrosine 64 to alanine (pVPg5A1) or tyrosine 64 and glycine 54 to alanines

135 (pVPg5A2). These peptides in fusion with GST were expressed and purified (Fig.

136 3C). The VPg5 mutants were analysed for their interaction with human elF4E (Fig.

137 3D). Both VPg5 mutants interact rather weakly with human elF4E, only slightly better

138 than with GST. Interestingly, rather weak interaction could be observed also for a

139 complete VPg protein (but which was on the same level as that shown in Fig. 2).

140 Effect of VPg peptides on neoplastic cells in culture. This effect was

141 investigated on HCT116 colon carcinoma cells in culture, transduced with Tat fusions

142 of VPg5 and VPg5A2. Treatment of neoplastic cells with TAT-VPg5 resulted in

143 marked cell death, while TAT-VPgA2 despite low binding to elF4E appears to act

144 only somewhat less well than Tat-VPg5 (Fig. 4). Cell death induced by Tat-VPg5 was

145 accompanied by reduction in elF4E level (Fig.4, BC). 


\section{Discussion}

148 Nuclear elF4E participates in a variety of important RNA processing events 149 including nucleocytoplasmic transport of specific, growth regulatory mRNAs. Indeed,

150 the availability of elF4E is believed to be critical for nuclear export and translational 151 activation of capped mRNAs with extensive secondary structures in their $5^{\prime}$ 152 untranslated regions (UTRs) (20), many of which code for the labile regulatory 153 proteins essential for cell growth or viability. Various molecular mechanisms of cell 154 growth converge on elF4E, and it appears that elF4E is a critical node in RNA 155 regulation influencing nearly every stage of cell cycle progression (16). Thus, elF4E, 156 besides its direct cytoplasmic role in protein synthesis, seems to have another, 157 nuclear function, whereby by promoting the export of messenger RNA of several 158 proteins involved in cell cycle it plays a key role in regulation of cell growth and 159 survival.

160 Elevated expression of elF4E leads to oncogenic transformation in tissue culture, 161 cancers in animal models and poor prognosis in some human cancers. Reduction of 162 elF4E level can reverse the transformed phenotype, which suggests that elF4E could 163 be exploited as a therapeutic target. A validation of elF4E as a therapeutic target has 164 been provided by in vivo experiments, in which suppression of elF4E expression in 165 mice by elF4E-specific antisense oligonucleotides (ASO) reduced tumor growth in 166 mice (21). Despite reducing the elF4E levels in mouse liver by $80 \%$, administration 167 of elF4E-specific ASO did not affect the body weight or the liver enzymes. This 168 suggested that the malignant tumors might be more susceptible to elF4E inhibition 169 than the normal tissues. Most importantly, a human trial on acute myeloid leukemia 170 patients in whom elF4E was inactivated with ribavirin, a cap structure mimic (and 171 thus an elF4E inhibitor) resulted in tumor growth inhibition and cancer remission that 
172 were correlated with elF4E reduction and translocation of nuclear elF4E to the

173 cytoplasm in blasts $(15,22)$. Recently, a phase I trial of ribavirin and low-dose

174 cytarabine for the treatment of acute myeloid leukemia with elevated elF4E has been

175 terminated, showing that the combination was well tolerated, with some patients

176 having a full molecular response with both reduction of elF4E levels and elF4E re-

177 localization to cytoplasm (23).

The elF4E binding partners such as 4E-BPs, Gemin5, Xenopus Maskin and mammalian neuroguidin, have all been shown to exert translational control (24).

180 These factors usually block the interaction between elF4E and the scaffold-like 181 elF4G factor, involved in the formation of the large translation initiation complex 182 elF4F (25). They all contain the dorsal elF4E-binding motif YxxxxL $\varnothing$. Another type 183 of elF4E effectors, the PML protein and the arenaviral protein $\mathrm{Z}$ use their respective 184 RING domains to directly interact with the dorsal surface of elF4E, thus reducing the 185 affinity of elF4E for its ligand, 5' cap of mRNA $(26,27)$. These two proteins shuttle 186 between nucleus and cytoplasm (28), and thus can interact with both nuclear and 187 cytoplasmic elF4E pools. In addition, a transcription factor, homeodomain protein $188 \mathrm{PRH} / \mathrm{HEX}$ that binds nuclear elF4E inhibits elF4E function only when its NLS is intact, 189 i.e. it must be nuclear to inhibit elF4E (29), whereas VPg protein delivered alone 190 shows an exclusively cytoplasmic localization. More importantly, VPg does not 191 contain the elF4E-binding motif $Y x x x x L \varnothing$ or the RING domain, which suggests that 192 VPg interaction with elF4E occurs at different elF4E site. Some plants became 193 resistant to potyviruses due to the elF4E mutations abolishing interaction with VPg. 194 Such mutations have been identified in two elF4E regions; one partially overlapping 195 the interior of the cap-binding pocket (which is in the concave part of elF4E) and 196 another on the surface of elF4E facing $90^{\circ}$ from the cap-binding site $(30,7)$. Both 
197 these regions are distant from the dorsal elF4E site attaching $Y x x x x L \varnothing$ peptides.

Another member of elF4E family of translational initiation factors that interact with

199 the 5'cap structure of mRNA is 4E-HP. However, 4E-HP does not share the role of

200 elF4E in mRNA transport from nucleus to cytoplasm; it is found exclusively in the

201 cytoplasm whereby it may act as a translational repressor of mRNAs (31). The third

202 member of the elF4E family, elF4E3, that share $\sim 25 \%$ identity and $\sim 50 \%$ similarity

203 with the two other elF4E family members, and is nuclear and cytoplasmic, also binds

204 the $\mathrm{m7G}$ cap, but acts as a tumor suppressor, competing with the growth-promoting

205 functions of elF4E (18). All these observations together show that VPg protein is

206 novel type of elF4E inhibitor.

207 Different type of elF4E inhibitor in a form of a cap analog was used by us during 208 in vivo studies in the animal model of hepatocellular carcinoma. HCC is one of the

209 leading causes of cancer-related death worldwide, one of the most lethal,

210 chemoresistant and prevalent cancers in the human population with limited treatment

211 options (32). It has been shown that HCC development depended on elF4E

212 overexpression (33). We have demonstrated that elF4E inhibition with cap analog in

213 the orthotopic rat model of HCC resulted in tumor growth inhibition, accompanied by

214 decrease in the level of two pro-oncogenes, elF4E and c-myc (34). Of nWojtl et al,

215 Mrch 2018ote, c-myc is amplified in up to $50 \%$ of HCC cases (35).

216 This time we used a peptide-type inhibitor of elF4E to find out whether inhibition

217 of the elF4E activity is an interesting therapeutic approach to cancer treatment that 218 conceivably could be extended to other neoplasms driven by elF4E overexpression.

219 A partially identified site on PVY VPg served here as a source of five peptides, out of

220 which some interacted better with elF4E than complete VPg protein. We have chosen

221 a peptide VPg5 of 26 amino acid residues that strongly interacted with elF4E (Figs. 
2 and 3). In parallel we designed a mutant VPg5A2, which showed rather low-level

223 interaction with elF4E. These peptides were delivered to neoplastic HCT116 cells in

224 a form of the N-terminal fusions with transducing Tat peptide (36). As use of Tat

225 peptide might introduce several artefacts, we followed the conditions developed for

226 minimizing the nonspecific Tat peptide activity (37). Viability of neoplastic cells was

227 significantly diminished by addition of Tat-VPg5 peptides, in a dose dependent 228 manner, quite strongly with the original VPg5 peptide, somewhat less with VPg5A2

229 peptide. Of note, designing the control - elF4E-nonreacting - peptide is rather difficult,

230 as there is no structural data identifying the amino acid residues of PVY VPg 231 interacting with elF4E.

232 It is possible that NLS of VPg (probably starting from ${ }^{41} \mathrm{Arg}$ ) is not functioning when

233 the complete protein (188 amino acid residues) is delivered upon expression in insect

234 cells, as complete VPg brought alone was localized exclusively to cytoplasm (Fig. 1).

235 However, it is quite plausible to think that NLS in the VPg5 peptide could be functional

236 and VPg5 would go directly to the nucleus, interacting there with the pro-oncogenic

237 nuclear elF4E. Nevertheless, the elF4E localization seen after treatment with VPg5

238 (Fig. 4 B,C) shows strong reduction of nuclear elF4E but nearly complete depletion

239 of factor in the cytoplasm. Further experiments including confocal microscopy would

240 more precisely describe the intracellular effect and localization of VPg5.

241 In conclusion, results obtained with VPg5 peptide show its activity as a novel,

242 efficient inhibitor of elF4E, leading to death of neoplastic cells, which is accompanied

243 by reduction in elF4E level. This kind of specific oncogene elF4E inhibitors should

244 be analysed in elF4E-driven cancers; it was thought that about $30 \%$ of human

245 malignancies show overexpression of elF4E (38), however, more detailed data

246 indicate this percent as close to $63 \%(39)$. 


\section{Acknowledgements.}

248 This work was in part financed by the French Associations Gefluc and Espoir and

249 the Polish National Science Centre. The funders had no role in study design, data

250 collection and interpretation, or the decision to submit the work for publication. The

251 authors have no conflict of interest to declare. 


\section{Materials and methods}

254 Materials. T. ni insect cells (Invitrogen) were grown as described by Grzela et al

255 (19). Anti-elF4E mAb that recognized human and animal elF4E was from Santa Cruz

256 Biotechnology (USA). Anti-eIF4E recognizing human, mouse and insect elF4E, was

257 a gift of Nahum Sonenberg (McGill University, Canada). Anti-VPg rabbit polyclonal

258 antibody was prepared in ESD (France), using as antigen PVY hisVPg expressed in

259 baculovirus (19) and was affinity-purified with VPg immobilized on CNBr-activated

260 Sepharose 4B (Amersham Bioscience). Goat anti-GST-HRP antibody was from

261 Rockland Immunochemicals Inc. Molecular weight markers for SDS-PAGE were from

262 Thermo Scientific. Rabbit polyvalent anti-Dd serum was prepared in the laboratory

263 using as antigen a mixture of well-formed and ultrasound-treated Dd.

Localization of elF4E and VPg in insect cells. T. ni cells $\left(2 \times 10^{6} \mathrm{cells} / \mathrm{ml}\right)$ were infected at $\mathrm{MOI} 10$ with recombinant baculoviruses or empty bacmid. Cells were collected at indicated times p.i., washed with PBS, fixed in cold $2 \%$ PFA and suspended in $300 \mu \mathrm{l}$ PBS. Portions of $100 \mu \mathrm{l}$ of fixed cells on round coverslips inserted into wells of a 24-wells plate and rehydrated were permeabilized with cold 0.1\% Trition X-100/PBS, rinsed twice with PBS and blocked with 5\% serum/PBS for

$27030 \mathrm{~min}$ at RT. Permeabilized cells were incubated for $1 \mathrm{~h}$ with anti-his or anti-elF4E

271 Ab diluted 100-fold, washed and incubated for $1 \mathrm{~h}$ with anti-rabbit FITC-conjugated

272 Ab or anti-mouse Texas Red-conjugated Ab (Jackson ImmunoResearch), diluted

273 1:100. Nuclei were stained with PI in PBS $(1 \mu \mathrm{g} / \mathrm{ml})$ and PBS-rinsed coverslips were 274 mounted with $50 \%$ glycerol. Images were collected with Bio-Rad MRC-600 laser 275 scanning confocal apparatus coupled to a Nikon Optiphot microscope.

Insect cell fractionation. High Five cells $\left(2 \times 10^{6}\right.$ cells $\left./ \mathrm{ml}\right)$ were infected with the 
278 bacmid. The infected cells were collected at the indicated times p.i. by centrifugations

279 at $2000 \mathrm{rpm}$ for $10 \mathrm{~min}$ and nuclei were separated from the soluble fraction as

280 described (Xu et al, 1995). Cytoplasmic and nuclear fractions were run on 15\% SDS-

281 PAGE followed by Western blot with anti-elF4E antibody and the ECL system.

282 Densitometry of elF4E bands was performed with GelDoc 2000 (BioRad, Quantity

283 One software).

Protein expression and purification. VPg expression in $E$. coli and purification was done according Grzela et al (19). GST protein was expressed in E. coli BL21(DE3) Rosetta from pGEX-4TI and purified on the GST-Sepharose. For the synthesis of the fusion protein GST-VPg5, the VPg5 gene encoding a part of VPg 288 protein between residues 41 - 66, was amplified by PCR using plasmid pGEXVPg

289 (containing the gene encoding the VPg protein of PVY strain 0, acc. no Z29526; 290 Grzela et al., 2006) as template, with the forward primer 291 5'CGCGGATCCGAAAACCTGTATTTTCAGGGCAGGAAAAAGGGAAAAGGTAAA 292 GG3' and the reverse primer 5'CCGCCGCTCGAGCTATTAGAACCCGTACATGTTAATGAA3'. The resulting PCR product was then digested by BamHI/Xhol and inserted into pGEX4T-1 vector between BamHI and Xhol sites for expression in E. coli as GST-fusion protein.

298 fusion with the GST protein (at the N-terminus of the peptide). To obtain GST299 VPg5A2, mutagenesis was done using Q5® Site-Directed Mutagenesis Kit (NEB) 300 and a GST-VPg5 in pGEX4T-1 as a template. In VPg5A1 the Gly54 has been 301 changed to Ala, in VPg5A2 both Gly54 and Tyr64 has been changed to Ala. The 302 following primers (forward and reverse, $F$ and R) have been used for mutagenesis of 
303 the pVPg5 sequence. The correct sequence of mutants was confirmed by DNA

304 sequencing.

$305 \quad$ VPg5A1

F1A AGCAGGAGGTTCATTAACATGGCCGGGTTCTAATAGCTCGAG

R1A TGACTTGCCCATACCAACTGTGGTACCTTTACC

VPg5A2

$309 \quad F 2 A$

AAAGGTACCACAGTTGGTATGGCCAAGTCAAGCAGGAGGTTCATTAACAT

GGCCGGGTTCTAATAG

$\mathrm{R} 2 \mathrm{~A}$

GAACCAG

GST peptides were expressed in E. coli Rosetta2(DE3)pLyS as follows.

Bacteria were grown in the presence of $100 \mu \mathrm{g} / \mathrm{ml}$ of carbenicilillin and $20 \mu \mathrm{g} / \mathrm{ml}$ chloramphenicol, initially at $37^{\circ} \mathrm{C}$. Protein production was induced with $400 \mu \mathrm{M}$ IPTG

318 at $\mathrm{OD}_{600}$ equal 0.6 , then the temperature was switched to $30^{\circ} \mathrm{C}$ and $4 \mathrm{~h}$ later the

319 bacteria were harvested. Cell pellet from $250 \mathrm{ml}$ culture was suspended in $10 \mathrm{ml}$ of

32050 mM Hepes buffer, pH 7.4, containing 300 mM NaCl, 5 mM DTT, 0.5 mM EDTA

321 and supplemented with the protease inhibitor cocktail (Complete, Roche) and

322 lysozyme (LabEmpire) at $1 \mathrm{mg} / \mathrm{ml}$. The bacteria were lysed by sonication on ice. The

323 lysates were then centrifuged at $14000 \mathrm{rpm}$ for $30 \mathrm{~min}$ at $4^{\circ} \mathrm{C}$ and the supernatants

324 were filtered through $0.2 \mu \mathrm{m}$ filter before applying onto $0.5 \mathrm{ml}$ Glutathione-Sepharose

325 4B column (GE Healthcare). After 4 washes with $10 \mathrm{ml}$ of lysis buffer GST-fusion

326 proteins were eluted with five $1 \mathrm{ml}$ portions of $10 \mathrm{mM}$ reduced glutathione in lysis

327 buffer. 
Human elF4E was cloned in plasmid pETM30 (EMBL) with 6xhis tag attached at the N-terminus. The protein was expressed in E. coli BL21(DE3) and purified by

330 affinity chromatography on a nickel column (HisTrap HP, GE-Healtcare). Plant elF4E

331 was prepared in fusion with GST tag attached at the N-terminus in plasmid pGEX4T-

3321 and expressed in E. coli BL21(DE3). The protein was purified on a Glutathione-

333 Sepharose 4B column.

Interaction of GST-VPg peptides with human elF4E (ELISA). The 96-well plates (Nunc) were coated with human elF4E in $0.1 \mathrm{M}$ carbonate buffer, $\mathrm{pH} 9.6$ (100 ng/well), and incubated overnight at $4^{\circ} \mathrm{C}$. Excess elF4E was removed and the wells were blocked with $5 \%$ milk in PBST for 1 hour at $37^{\circ} \mathrm{C}$. After milk removal the plates

338 were washed four times (5 min each) with PBST. Two-fold dilutions in cascade of

339 fusion proteins GSTVPg, GSTVPg5, GSTVPg5A1, GSTVPg5A2 and GST alone 340 (2000 $-0.97 \mathrm{nM})$ were added to the wells and allowed to incubate for 90 min at RT.

341 After removal of proteins excess the wells were washed two times (5 min each) with 342 PBST. Next, the plates were incubated for 1 hour at $37^{\circ} \mathrm{C}$ with anti-GST-HRP 343 antibody diluted 1:10 000. Excess antibody was removed, the plates were washed 344 three times with PBST and the color reaction was revealed with TMB (Thermo 345 Scientific) and terminated 20 min later with $2 \mathrm{M} \mathrm{H}_{2} \mathrm{SO}_{4}$. The absorbance at $450 \mathrm{~nm}$ 346 was measured with the BIO-TEK Synergy HT fluorimeter.

347 TAT-VPg peptides. For delivery to human cells in culture, peptides VPg5 and 348 VPg5A2 have been synthesized by Pepscan Presto BV (The Netherlands) as N349 terminal TAT fusion peptides, with over $90 \%$ of purity. 
Tat-VPg5A2 - NH2-RKKRRQRRR-RKKGKGKGTT VGMAKSSRRF INMAGF$\mathrm{CONH}_{2}$

Effect of Tat-VPg peptides on viability of neoplastic cells in culture. HCT116 cells were maintained in RPMI 40 medium containing $10 \%$ fetal bovine serum (FBS), and antibiotics (100 $\mathrm{mg} / \mathrm{mL}$ streptomycin, $100 \mathrm{U} / \mathrm{mL}$ penicillin) at $37^{\circ} \mathrm{C}$ in a humidified atmosphere of $95 \%$ air and $5 \% \mathrm{CO}_{2}$. They were seeded into 24 -well dishes at $1 \times 10^{5}$ and left overnight. The medium was removed, cells rinsed with PBA and Tat-VPg peptides dissolved in PBS were added for indicated times. The viability was estimated by trypan blue inclusion. The results are expressed as an average of three measurements.

Level of eIF4E in nuclear and cytoplasmic fraction of HCT116 cells. Before and after treatment with Tat-VPg peptides, HCT116 cells were scraped and fractionated according to REAP method (40). Proteins in cytosol and in the nuclear fraction were fractionated on SDS-PAGE (Mini-protean TGX precast gel from BioRad), transferred to the PVDF membrane using the Trans-Blot Turbo transfer apparatus (BioRad). The elF4E was revealed with rabbit polyclonal Ab (kind gift of Nahum Sonenberg) at 1:1000 using ECL system (BioRad) and ChemiDoc XRS+ imager (BioRad) for visualisation. Densitometric analysis was done on elF4E bands using ImageLab software version 4.1 (BioRad).

Acknowledgement. We are indebted to Siergiej Tcherniuk for gift of the 373 plasmid expressing human elF4E, to N. Sonenberg for gift of the elF4E antibodies 374 and to L. Strokowskaja and A. Chachulska for gift of the recombinant baculovirus 375 expressing domain II of HCV helicase. RG was the recipient of EMBO and NATO 376 short-term fellowships. This study was in part supported by NATO CLG 982385 grant, 
bioRxiv preprint doi: https://doi.org/10.1101/298455; this version posted April 10, 2018. The copyright holder for this preprint (which was

not certified by peer review) is the author/funder, who has granted bioRxiv a license to display the preprint in perpetuity. It is made available under aCC-BY-NC-ND 4.0 International license.

377 ANR 08-EBIO-023 grant, by a Gefluc and Espoir grants and by the Polish Ministry of

378 Sciences and Higher Education grant N302 044 32/3571.

379 


\section{References}

1. Jiang J, Laliberté JF. 2011. The genome-linked protein VPg of plant viruses-a protein with many partners. Curr Opin Virol 1:347-54.

2. Cheng X, Wang A. 2016. The Potyvirus Silencing Suppressor Protein VPg Mediates Degradation of SGS3 via Ubiquitination and Autophagy Pathways. J Virol 91:pii e01478-16.

3. Yeam I, Cavatorta JR, Ripoll DR, Kang BC, Jahn MM. (). Functional dissection of naturally occurring amino acid substitutions in elF4E that confers recessive potyvirus resistance in plants. Plant Cell 2007;19:2913-28.

4. Wang X, Kohalmi SE, Svircev A, Wang A, Sanfaçon H, Tian L. 2013. Silencing of the host factor elF(iso)4E gene confers plum pox virus resistance in plum. PLoS One 8:e50627.

5. Li H, Kondo H, Kühne T, Shirako Y. 2016. Barley Yellow Mosaic Virus VPg Is the Determinant Protein for Breaking elF4E-Mediated Recessive Resistance in Barley Plants. Front Plant Sci. 7:1449.

6. Duan H, Richael C, Rommens CM. 2012. Overexpression of the wild potato elF4E-1 variant Eva1 elicits Potato virus $\mathrm{Y}$ resistance in plants silenced for native elF4E-1. Transgenic Res 21:929-938.

7. Ashby JA, Stevenson CE, Jarvis GE, Lawson DM, Maule AJ. 2011. Structurebased mutational analysis of elF4E in relation to sbm1 resistance to pea seed-borne 400 mosaic virus in pea. PLoS One 6:e15873.

401 8. Martínez-Silva AV, Aguirre-Martínez C, Flores-Tinoco CE, Alejandri-Ramírez 402 ND, Dinkova TD. 2012. Translation initiation factor AtelF(iso)4E is involved in selective 
family members. Eur J Biochem 271:2189-203.

$$
\text { 10. Lejbkowicz F, Goyer C, Darveau A, Neron S, Lemieux R, Sonenberg N. } 1992 .
$$

A fraction of the mRNA 5' cap-binding protein, eukaryotic initiation factor 4E, localizes to the nucleus. Proc Natl Acad Sci U S A 89:9612-6

$$
\text { 11. Strudwick S, Borden KL. 2002. The emerging roles of translation factor elF4E }
$$
in the nucleus. Differentiation 70:10-22.

12. Sonenberg N, Gingras AC. 1998. The mRNA 5' cap-binding protein elF4E and control of cell growth. Curr Opin Cell Biol 10:268-7513.

13. Sonenberg N. 2008. elF4E, the mRNA cap-binding protein: from basic discovery to translational research. Biochem Cell Biol 86:178-83

14. Siddiqui N, Sonenberg N. 2015. Signalling to elF4E in cancer. Biochem Soc Trans 43:763-72

15. Assouline S, Culjkovic B, Cocolakis E, Rousseau C, Beslu N, Amri A, Caplan S, Leber B, Roy DC, Miller WH Jr, Borden KL. 2009. Molecular targeting of the oncogene elF4E in acute myeloid leukemia (AML): a proof-of-principle clinical trial with ribavirin. Blood114:257-60.

16. Culjkovic B, Topisirovic I, Skrabanek L, Ruiz-Gutierrez M, Borden KL. 2006. elF4E is a central node of an RNA regulon that governs cellular proliferation. J Cell Biol 175:415-26.

17. Culjkovic B, Tan K, Orolicki S, Amri A, Meloche S, Borden KL. 2008. The elF4E RNA regulon promotes the Akt signaling pathway. J Cell Biol 181:51-63.

18. Osborne MJ, Borden KL. 2015. The eukaryotic translation initiation factor elF4E in the nucleus: taking the road less traveled. Immunol Rev. 263:210-23. 
19. Grzela R, Strokovska L, Andrieu JP, Dublet B, Zagorski W, Chroboczek J.

429 2006. Potyvirus terminal protein VPg, effector of host eukaryotic initiation factor

430 elF4E. Biochimie 88:887-96.

431 20. Larsson O, Perlman DM, Fan D, Reilly CS, Peterson M, Dahlgren C, Liang Z,

432 Li S, Polunovsky VA, Wahlestedt C, Bitterman PB. 2006. Apoptosis resistance 433 downstream of elF4E: posttranscriptional activation of an anti-apoptotic transcript 434 carrying a consensus hairpin structure. Nucleic Acid Res 34:4375-86.

435 21. Graff JR, Konicek BW, Vincent TM, Lynch RL, Monteith D, Weir SN, Schwier

436 P, Capen A, Goode RL, Dowless MS, Chen Y, Zhang H, Sissons S, Cox K, McNulty 437 AM, Parsons SH, Wang T, Sams L, Geeganage S, Douglass LE, Neubauer BL, Dean 438 NM, Blanchard K, Shou J, Stancato LF, Carter JH, Marcusson EG. 2007. Therapeutic 439 suppression of translation initiation factor elF4E expression reduces tumor growth $440 \quad$ without toxicity. J Clin Invest 117:2638-48.

441 22. Borden KL. 2011. Targeting the oncogene elF4E in cancer: From the bench to 442 clinical trials. Clin Invest Med 34:E315.

443 23. Assouline S, Culjkovic-Kraljacic B, Bergeron J, Caplan S, Cocolakis E, 444 Lambert C, Lau CJ, Zahreddine HA, Miller WH Jr, Borden KL. 2015. A phase I trial 445 of ribavirin and low-dose cytarabine for the treatment of relapsed and refractory acute 446 myeloid leukemia with elevated elF4E. Haematologica100:e7-9.

447 24. Rhoads RE. 2009. elF4E: new family members, new binding partners, new 448 roles. J Biol Chem 284:16711-5.

449 25. Gingras AC, Raught B, Sonenberg N. 1999. elF4 initiation factors: effectors of 450 mRNA recruitment to ribosomes and regulators of translation. Ann Rev Biochem 68:913-63. 
26. Cohen N, Sharma M, Kentsis A, Perez JM, Strudwick S, Borden KL. 2001. PML RING suppresses oncogenic transformation by reducing the affinity of elF4E for mRNA. EMBO J 20:4547-59. characterization of the Z RING-eIF4E complex reveals a distinct mode of control for elF4E. Proc Natl Acad Sci U S A 107:5441-6.

28. Maul GG, Negorev D, Bell P, Ishov AM. 2000. Review: properties and assembly mechanisms of ND10, PML bodies, or PODs. J Struct Biol 129:278-87. The proline-rich homeodomain protein, $\mathrm{PRH}$, is a tissue-specific inhibitor of elF4Edependent cyclin D1 mRNA transport and growth. EMBO J 22:689-703.

30. Charron C., Nicolai M., Gallois J.L., Robaglia C., Moury B., Palloix A., Caranta C. 2008. Natural variation and functional analyses provide evidence for co-evolution between plant elF4E and potyviral VPg. Plant J 54:56-68.

31. Villaescusa JC, Buratti C, Penkov D, Mathiasen L, Planagumà J, Ferretti E,

Blasi F. 2009. Cytoplasmic Prep1 interacts with 4EHP inhibiting Hoxb4 translation. PLoS One 4:e5213.

32. Maluccio M, Covey A. 2012. Recent progress in understanding, diagnosing, and treating hepatocellular carcinoma. CA Cancer J Clin 62:394-9.

472 JW, Dombrowski F, Calvisi DF, Evert M, Chen X. 2015. 4EBP1/elF4E and 473 p70S6K/RPS6 axes play critical and distinct roles in hepatocarcinogenesis driven by 474 AKT and N-Ras proto-oncogenes in mice. Hepatology 61:200-13.

475 34. Zochowska M, Piguet AC, Jemielity J, Kowalska J, Szolajska E, Dufour JF, 476 Chroboczek J. 2015. Virus-like particle-mediated intracellular delivery of mRNA cap 
477 analog with in vivo activity against hepatocellular carcinoma. Nanomedicine 11:67-

47876.

479 35. Beer S, Zetterberg A, Ihrie RA, McTaggart RA, Yang Q, Bradon N, Arvanitis

480 C, Attardi LD, Feng S, Ruebner B, Cardiff RD, Felsher DW. 2004. Developmental

481 Context Determines Latency of MYC-Induced Tumorigenesis. PLoS Biol 2:e332.

482 36. Joliot A, Prochiantz A. 2004. Transduction peptides: from technology to 483 physiology. Nature Cell Biology 6:189-196.

484 37. Jones SW, Christison R, Bundell K, Voyce CJ, Brockbank SM, Newham P, 485 Lindsay MA. 2005. Characterisation of cell-penetrating peptide-mediated peptide 486 delivery. Br J Pharmacol 145:1093-102.

487 38. Culjkovic B, Borden KL. 2009. Understanding and Targeting the Eukaryotic 488 Translation Initiation Factor elF4E in Head and Neck Cancer. J Oncol 2009:981679.

489 39. Fan S, Ramalingam SS, Kauh J, Xu Z, Khuri FR, Sun SY. 2009. 490 Phosphorylated eukaryotic translation initiation factor 4 (elF4E) is elevated in human 491 cancer tissues. Cancer Biol Ther 8:1463-9.

492 40. Suzuki K, Bose P, Leong-Quong RY, Fujita DJ, Riabowol K. 2010. REAP: A 493 two minute cell fractionation method. BMC Res Notes 3:294.

494 41. Schägger H, von Jagow G. 1987. Tricine-sodium dodecyl sulfate495 polyacrylamide gel electrophoresis for the separation of proteins in the range from 1 496 to $100 \mathrm{kDa}$. Anal Biochem 166:368-79 


\section{Figure legends}

Fig. 1. Effect of VPg on distribution of endogenous elF4E in insect cells.

500 Expressing insect cells were analyzed by confocal microscopy (x 60). (A) Localization

501 of elF4E (in green) in the presence of VPg (in red). (B) Cytoplasmic retention of native

502 elF4E (in green) is specific for VPg. (C) Distribution of endogenous insect elF4E upon

503 VPg expression (MOI 10). Expressing cells nuclei $(\mathrm{n})$ were separated from the

504 cytoplasm (c) and the elF4E content was analyzed. Recombinant proteins expression is shown in the lower far right panel.

Fig. 2. Interaction of VPg peptides with elF4E. (A) Amino acid sequence of VPg and VPg peptides derived from the VPg region involved in interaction with elF4E.

508 The putative elF4E interaction site is marked with bold letter. (B) Interaction of VPg peptides with wheat elF(iso)4E and human elF4E. Complete VPg protein is marked

510 in bold.

Fig. 3. VPg5 peptides and their interaction with human elF4E. (A) Comparison of primary sequence of some potyviral VPgs. (B) Primary sequence of VPg5 513 peptides. (C) GST-fusion proteins used in ELISA test, run on 15\% tricine 514 polyacrylamide gel (41). Samples of $1-2 \mu g$ were stained with CBB. Lane $1-V P g$ 515 protein, lane 2 - VPg5; lane 3 - VPg5A1; lane 4 - VPg5A2; lane 5 - his-elF4E protein;

516 lane 6 - GST protein. (D) Interaction of pVPg peptides with human elF4E (ELISA 517 sandwich technique).

518 Fig. 4. Effect of Tat-VPg peptides on HCT116 cell viability. Tat-VPg5 peptides 519 were applied to HCT116 cells as described in Materials and Methods. (A). Cell 520 viability was measured by trypan blue exclusion. B. Portions of 100000 cells 521 untreated or treated with Tat-VPg5 underwent fractionated with REAP method (40), 
bioRxiv preprint doi: https://doi.org/10.1101/298455; this version posted April 10, 2018. The copyright holder for this preprint (which was

not certified by peer review) is the author/funder, who has granted bioRxiv a license to display the preprint in perpetuity. It is made available under aCC-BY-NC-ND 4.0 International license.

522 run on SDS-PAGE gel, and Western blot was performed with anti-elF4E antibody.

523 Densitometry was performed as described in Materials and Methodes.

524 
Table 1. Distribution of elF4E in insect cells

$12 \mathrm{~h}$

bacmid

46.5

53.5

VPg

55.5

44.5

hisVPg

53.4

46.6

532

$24 \mathrm{~h}$

bacmid

57.8

42.2

544 elF4E level assessed by Western blot (Fig. 1C) was followed by densitometry. 

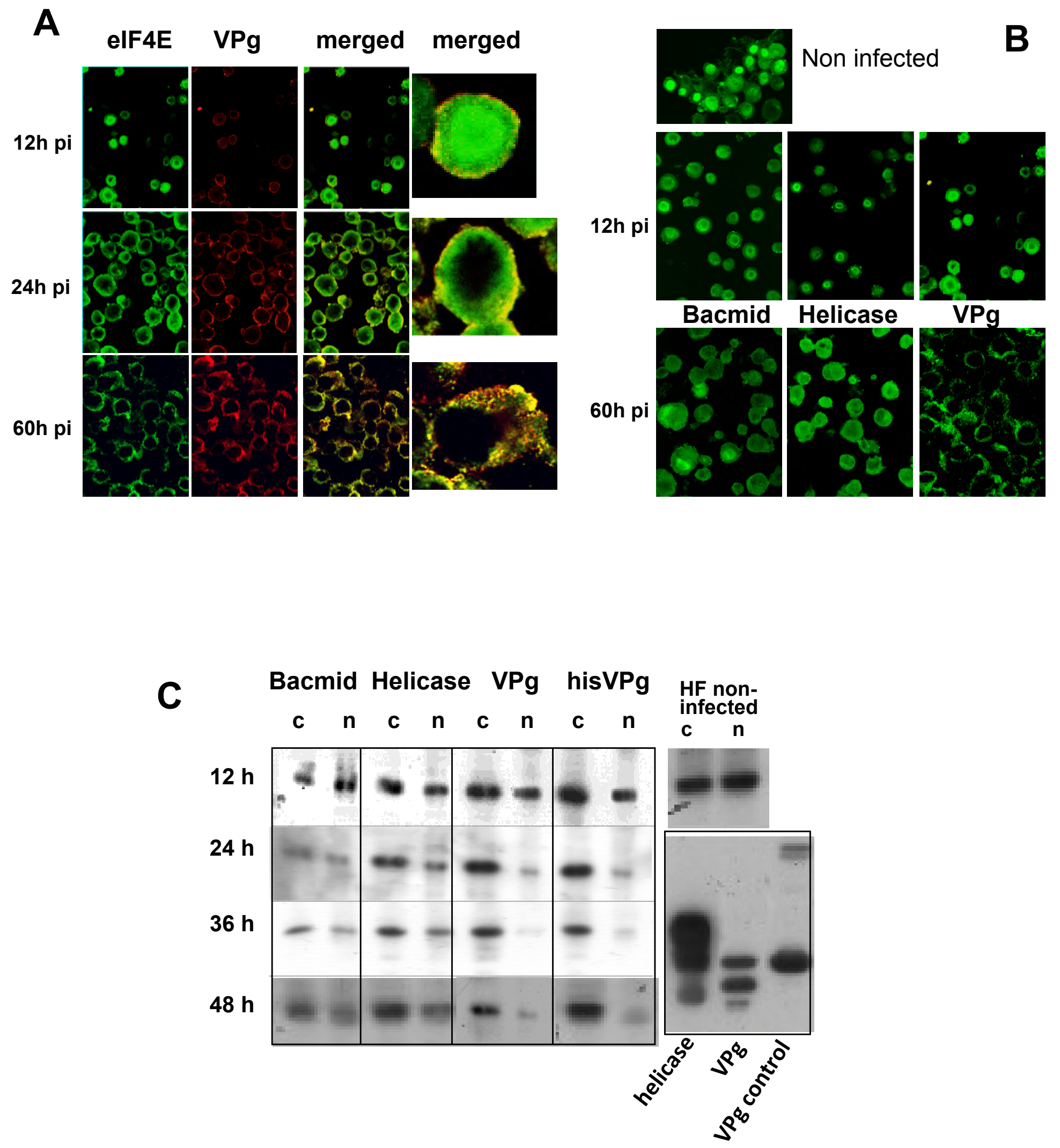

Fig. 1, Wojtal et al 
A ${ }^{1}$ GKNKSKRIQA LKFRHARDKR AGFEIDNNDD

TIEEFFGSAY RKKGKGKGTT VGMGKSSRRF INMYGFDPTE YSFIQFVDPL TGAQIEENVY

ADIRDIQERF SEVRKKMVEN DDIEMQALGS NTTIHAYFRK DWSDKALKID LMPHNPLKVC PVY VPg

DKTNGIAKFP ERELELRQTG PAVEVDVKDI

primary sequence

PAQEVEHE ${ }^{188}$

\section{VPg peptides}

VPg1, 19 aa 41-RKKGKGKGTTVGMGKSSRR-59

VPg2, 54 aa 41-RKKGKGKGTTVGMGKSSRRFINMYGFDPTEYSFIQFVDPLTGAQIEENVYADIR-94

VPg3, 34aa

60-FINMYGFDPTEYSFIQFVDPLTGAQIEENVYADIR-94

VPg4, 42aa 41-RKKGKGKGTTVGMGKSSRRFINMYGFDPTEYSFIQFVDPLTG-83

VPg5, 26aa 41-RKKGKGKGTTVGMGKSSRRFINMYGF-66

B
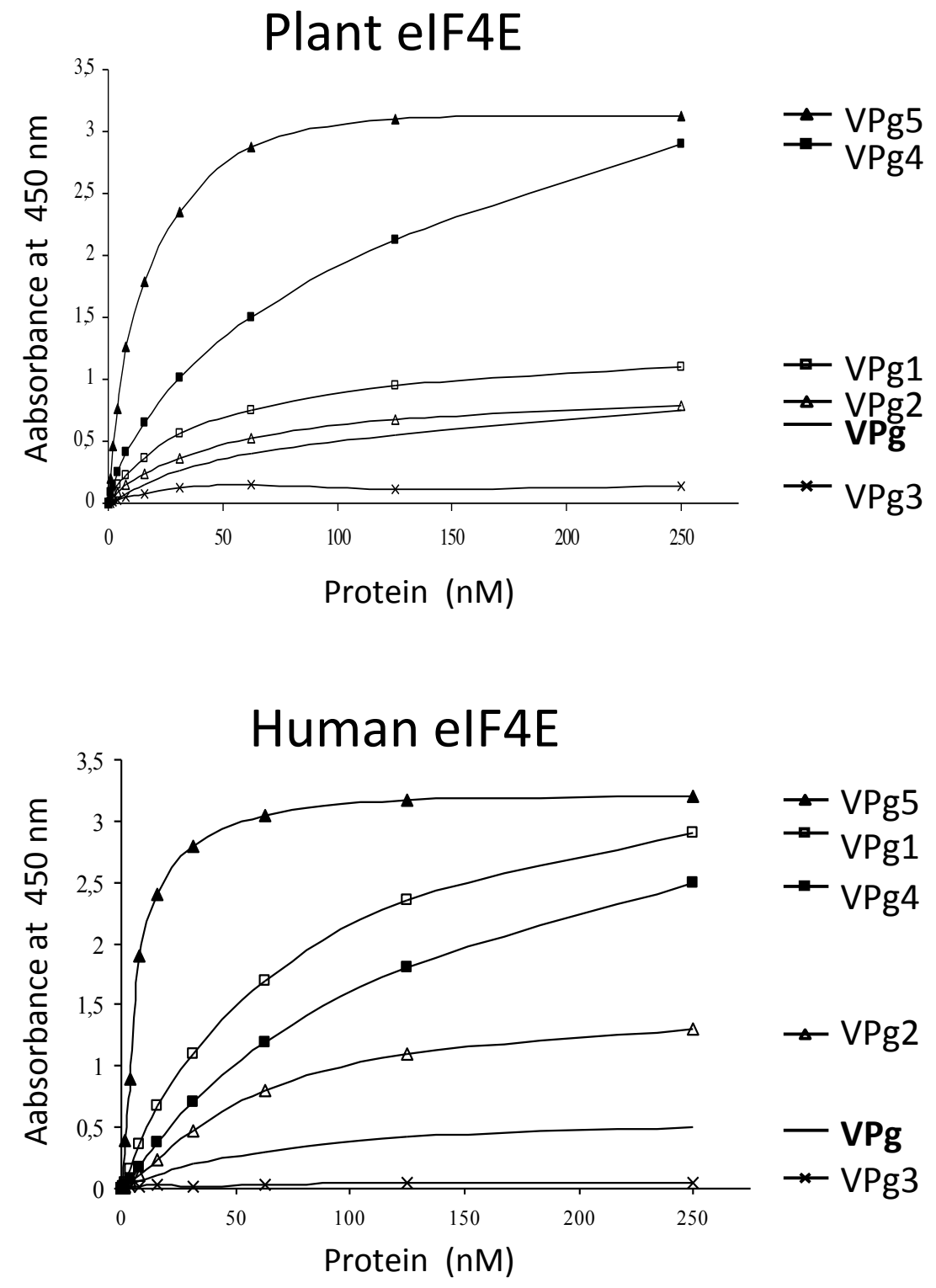

Fig. 2, Wojtal et al 
A PVY ${ }^{41}$ RKKGKGKGTT VGMGKSSRRF INMYGF

TEV NNKGKRKGTT RGMGAKSRKF INMYGF CIYVV SKKGKTKGTV VGLGAKTRRF TNMYGF TVMV TKKGKSKGKT HGAGTKAHKF VNMYGV LMV TEKGKKSGKT KGMGTKNRRF VNMYGY TuMV TKKGKSKGRT RGIGHKNRKF INMYGF

PVA TKKGKTKGKT HGMGKKNHRF VNMYGF

B

VPg5 RKKGKGKGTT VGMGKSSRRF INMYGF VPg5A1 RKKGKGKGTT VGMGKSSRRF INMAGF VPg5A2 RKKGKGKGTT VGMAKSSRRF INMAGF

C $\begin{array}{llllll}1 & 2 & 3 & 4 & 5 & 6\end{array}$

\section{5 \\ 34 \\ 26}

D

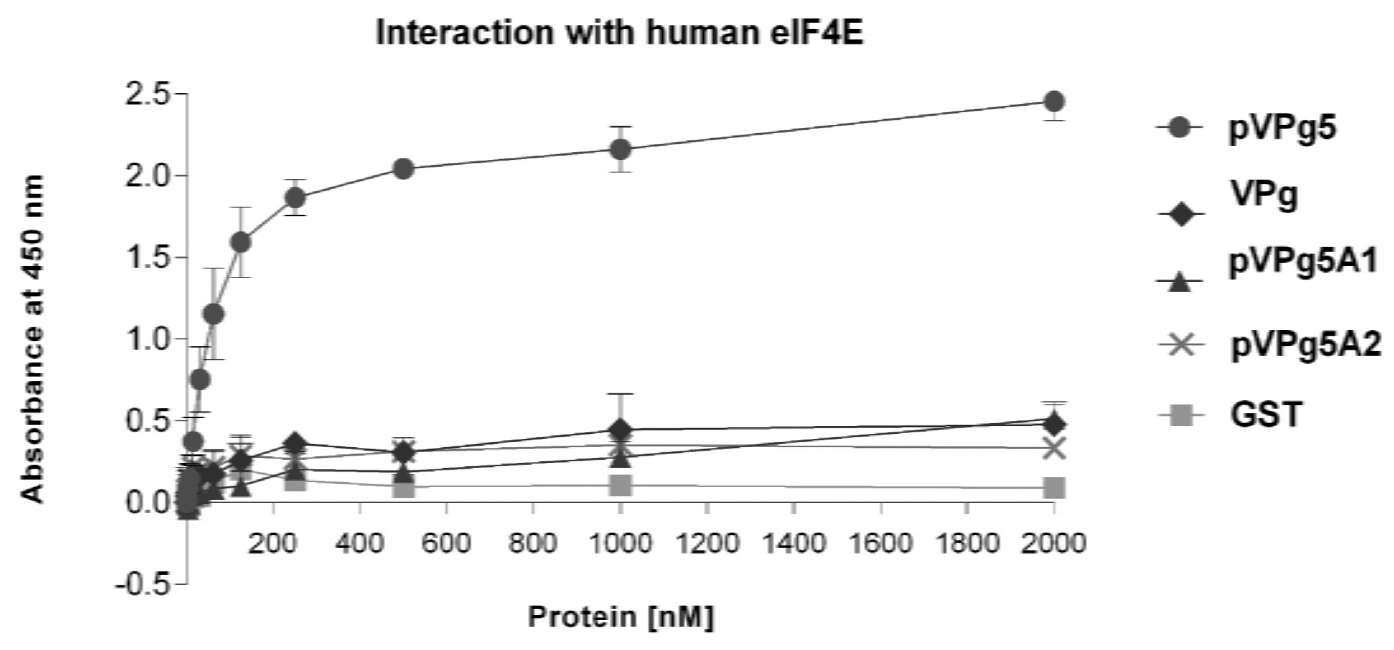

Fig. 3, Wojtal et al 
A
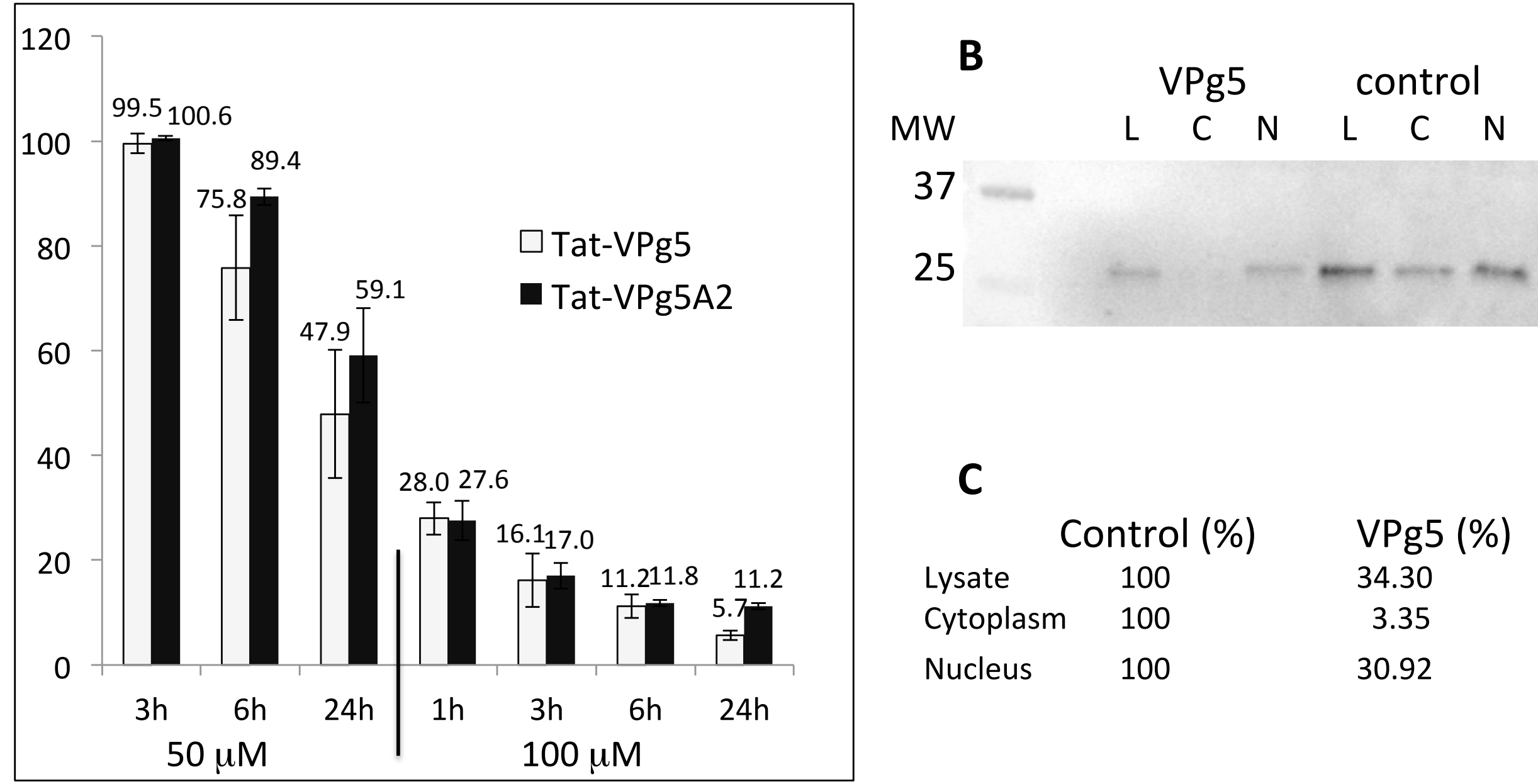

$\begin{array}{lcc} & \text { Control (\%) } & \text { VPg5 (\%) } \\ \text { Lysate } & 100 & 34.30 \\ \text { Cytoplasm } & 100 & 3.35 \\ \text { Nucleus } & 100 & 30.92\end{array}$

Fig. 4, Wojtal et al. 